\title{
A cladoceran similar to the American Diaphanosoma brevireme Sars, 1901 (Crustacea: Cladocera: Sididae) found in the Russian Far East
}

\author{
Кнадоџера близкая к американскому виду Diaphanosoma \\ brevireme Sars, 1901 (Crustacea: Cladocera: Sididae) найдена \\ на Аальнем Востоке России
}

\author{
N.M. Korovchinsky ${ }^{1}$, N.G. Sheveleva ${ }^{2}$ \\ Н.М. Коровчинский ${ }^{1}$, Н.Г. Шевелева ${ }^{2}$
}

\begin{abstract}
${ }^{1}$ A.N. Severtsov Institute of Ecology and Evolution of the Russian Academy of Science, Leninsky prospect 33, Moscow 119071 Russia; e-mail: nmkor@yandex.ru

${ }^{1}$ Институт проблем экологии и эволюции им. А.Н. Северцова РАН, Ленинский проспект 33, Москва 119071.

${ }^{2}$ Istitute of Limnology of the Siberian Branch of the Russian Academy of Sciences, Irkutsk 664033 Russia; e-mail: shevn@lin.irk.ru

2 Лимнологический институт СО РАН, Иркутск 664033
\end{abstract}

KEY WORDS: Cladocera, Diaphanosoma cf. brevireme, Zeya River basin, description.

КЛЮЧЕВЫЕ СЛОВА: Cladocera, Diaphanosoma cf. brevireme, бассейн реки Зеи, описание.

\begin{abstract}
Two specimens of the genus Diaphanosoma Fischer, 1850, morphologically similar to the American tropical-subtropical D. brevireme Sars, 1901, have been found in the Zeya River basin, a major northern tributary of the Amur River (Amursky District, Far East of Russia). Comparison of these specimens from the Zeya River with those of the latter species from Argentina, Brasilia, and Cuba has revealed some specific morphological differences but the material was not sufficient to complete the description of a probable new taxon of the species rank. The occurrence of specimens from the Far East in a cold, temperate water bodies and remoteness of their locality from those of close congeners support the idea of the relict status of the taxon.
\end{abstract}

РЕЗЮМЕ. Два экземпляра рода Diaphanosoma Fischer, 1850 (Cladocera: Sididae), морфологически сходные с американским тропическо-субтропическому видом D. brevireme Sars, 1901, найдены в бассейне реки Зеи - крупнейшего северного притока реки Амур (Амурская область, Дальний Восток России). Сравнение этих экземпляров из реки Зеи с особями последнего вида из Аргентины, Бразилии и Кубы выявило несколько специфических морфологических отличий, но материал не был достаточен для завершения описания вероятного нового таксона видового ранга. Обитание особей с Дальнего Востока в холодных водоемах умеренного климата и удаленность их местонахождения от таковых близкого вида поддерживает идею о реликтовом статусе данного таксона.

\section{Introduction}

The species Diaphanosoma brevireme was originally described from southeast Brasil (Itatiba in the vicinity of São Paulo City) by G.O. Sars [1901]. Later, it was redescribed by Paggi [1978] from the material from Argentina and Korovchinsky [1982, 1992] from the type material of Sars, few individuals of E. Daday from Paraguay, and specimens from Cuba. Thus, this species may be regarded comparatively well known in respect of its morphology; however, its morphological characters are variable, and so further investigation of this interpopulation variability would be valuable. The known range of $D$. brevireme comprises the vast area, from the north-east of Argentina to the southern United States [Korovchinsky, 2004].

Recently, specimens similar to D. brevireme were found in a sample collected by N.G. Sheveleva in the basin of Zeya River, one of the largest tributaries of the Amur River.

This record, together with some other peculiar taxa, was briefly noted in special overview publication [Kotov et al., 2011]. Here we provide more detailed description of these specimens of Diaphanosoma from the Zeya River basin.

\section{Material and methods}

Two damaged adult females of Diaphanosoma, one of which was gamogenetic, bearing a resting egg in the brood pouch, were collected in summer 2005 in a pond 


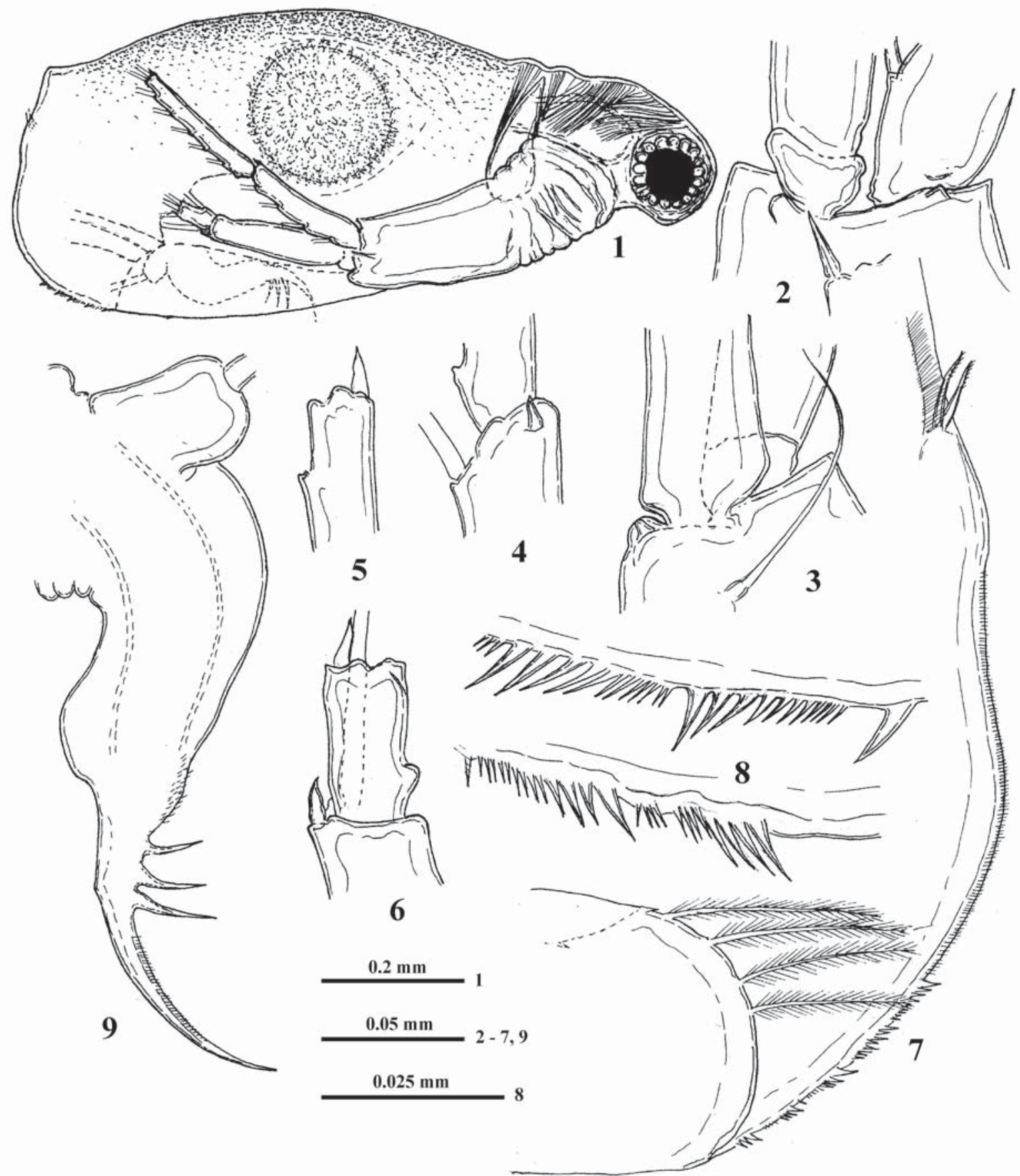

Figs 1-9. Diaphanosoma cf. brevireme, Zeya River basin: 1 - gamogenetic female, general lateral view; 2 - distal end of antennal basipodite, outer side; 3 - the same, inner side; 4 - distal end of proximal segment of two-segmented antennal exopodite; 5 - distal end of distal segment of two-segmented antennal exopodite; 6 - distal end of three-segmented antennal endopodite; 7 - posterior part of shell valve, inner view; 8 - denticles of postero-ventral valve margin; 9 - postabdomen, lateral view.

Pис. 1-9. Diaphanosoma cf. brevireme, бассейн реки Зеи: 1 - гамогенетическая самка, общий вид с боковой стороны; 2 дистальный конец базиподита антенн с внешней стороны; 3 - тоже самое с внутренней стороны; 4 - дистальный конец проксимального членика двухчленикового экзоподита антенны; 5 - дистальный конец дистального членика двухчленикового экзоподита антенны; 6 - дистальный конец трехчленикового эндоподита антенны; 7 - задняя часть створки раковинки с внутренней стороны; 8 - зубчики задне-нижнего края раковинки; 9 - постабдомен с боковой стороны. 
near Zeya Reservoir dam in Amursky District (Far East of Russia) $\left(53^{\circ} 43.850^{\prime} \mathrm{N} ; 127^{\circ} 16.176^{\prime} \mathrm{E}\right)$. Some specimens of D. brevireme from northeast Argentina, southeast of Brasilia, and Cuba were used for comparison.

The specimens were investigated using the dissecting microscope MBS-10 and compound microscope Olympus BX41 with camera lucida and photo camera Infinity 1.

\section{Description}

\section{Diaphanosoma cf. brevireme Sars, 1901}

Figs $1-10$.

The studied parthenogenetic and gamogenetic female did not differ morphologically, as it is usual for the cladocerans order Ctenopoda, despite the presence of a resting egg in the brood pouch of the latter one. For this reason, they are described below together. The body measurements were made only in less damaged gamogenetic female.

Head comparatively small (32\% of body length), roundish-rectangular, its dorsal margin clearly sloping to the front, and then smoothly joining the frontal margin (Fig. 1). Eye large (11.7\% of body length). Antennules comparatively large, with massive basal part. Swimming antennae short (64.1\% of body length), far not reaching the posterior valve margin. Their branches comparatively long, upper antennal branch (exopodite) is slightly longer than basipodite (1.0:0.9) while lower antennal branch (endopodite) is shorter than the basipodite $(0.8: 1.0)$. A stout sharp spine on the basipodite distal outer end, a rounded outgrowth near base of lower branch, and a small triangular outgrowth near base of upper branch (Fig. 2). Basipodite distal inner end bears a long seta (Fig. 3). Proximal segment of upper branch with a small, rather stout spine (Fig. 4) and distal segment of this branch bears a larger stout spine apically (Fig. 5). Similar spines are present on the ends of second and third segments of lower branch (Fig. 6). Antennal setae $4-8 / 0-1-4$. Ventral valve margins form a wide fold with free ventral margin folding inside and bearing a number of setae and small denticles (all of them were poorly visible in specimens available). Posterior margin of valve fold bears four long feathered setae (Fig. 7). Five or six groups of small denticles along the posteroventral valve margins, mostly with 11 to 13 denticles in each group, three-five of them are large and then considerably diminishing in size in ventral direction (Figs. $7,8)$. Posterior valve margin slightly protruding in lower part and armed by an inner row of small spinules. Two inner thorn-like spines of almost similar size, bearing tiny spinules near the upper posterior valve margin (Fig. 7). A row of long setules near them. Postabdomen (Fig. 9) with a conspicuous ventral prominence near the base of claws which bears three long basal spines of moderate stoutness. Gamogenetic female has a comparatively large and dark resting egg

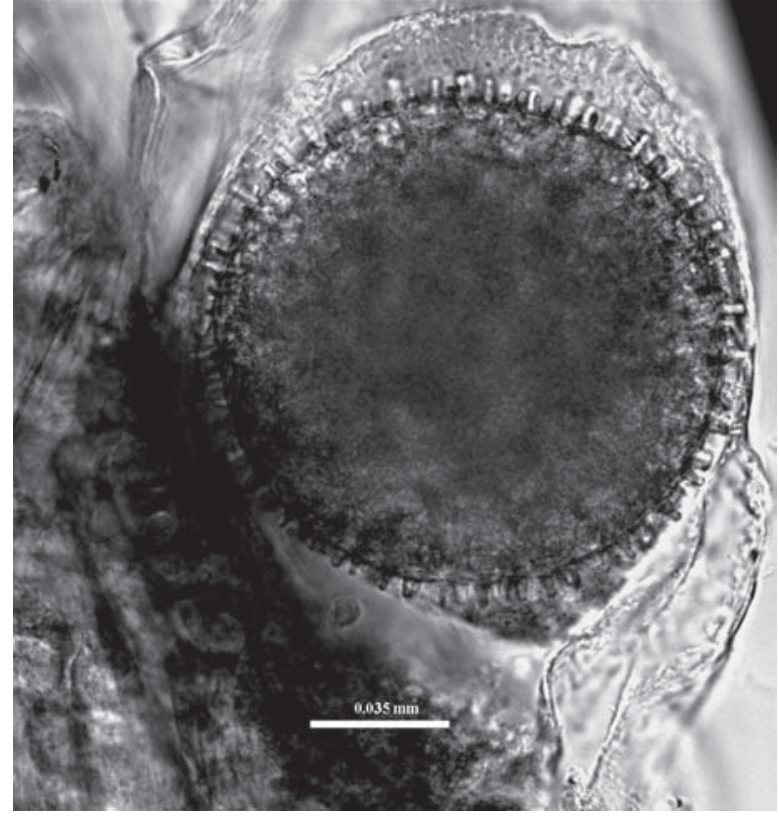

Fig. 10. Diaphanosoma cf. brevireme, Zeya River basin: resting egg.

Рис. 10. Diaphanosoma cf. brevireme, бассейн реки Зеи: стойкое яйцо.

(diameter $0.14 \mathrm{~mm}$ ) with numerous prominences in its brood pouch (Fig. 10).

Body length: $0.86 \mathrm{~mm}$ in parthenogenetic female and $0.80 \mathrm{~mm}$ in gamogenetic female.

\section{Remarks}

The studied specimens are very similar to $D$. brevireme s.str. in respect of most features. At the same time, they differ from specimens of latter species in absence of setules between long feathered setae on the posterior margin of ventral valve flap and the smaller size of denticles on the postero-ventral valve margins, the biggest of which do not exceed by much the smaller, neighboring denticles. Also, the size of two inner spines near posterior valve margins do not differ much as it is typical for D. brevireme.

\section{Discussion}

It seems quite probable that two specimens of the form under consideration belong to a new, not yet described species, but the two, partly deformed specimens are insufficient to establish a new species because the distinctive morphological characters of $D$. cf. brevireme are rather inconspicuous and need further verification. D. cf. brevireme possesses some characters, a wide ventral valve fold and resting eggs with numerous prominences, which are characteristic of some tropical-subtropical species but not temperate species of Diaphanosoma. In Eastern Hemisphere, the closest 
species with such characters, D. sarsi Richard, occupies all paleotropics with extensions to the northern Uzbekistan $\left(42-44^{\circ} \mathrm{N}\right)$ and North India (Kashmir, $32^{\circ}$ N) [Korovchinsky, 2004] which are situated far south from the locality of $D$. cf. brevireme.

At the same time, the occurrence of these specimens in the Zeya River basin, a cold, temperate Asian river $\left(53^{\circ} \mathrm{N}\right)$, contrasts sharply with $D$. brevireme s.str. which occurs in new world tropics and subtropics. Thus, the Zeya River specimens of Diaphanosoma occupy geographically a unique position being isolated very far from close congeners both in the American continent and in Asia. This and obvious rarity of the taxon suggest its relict nature sensu Korovchinsky [2006].

ACKNOWLEDGEMENTS. This work was supported by grants from the Program "Biodiversity and dynamics of genofonds" (1.1.8) and Russian Foundation of Basic Research (\# 09-04-00201a). Authors thank two anonymous reviewers for valuable corrections of the first draft of the manuscript.

\section{References}

Korovchinsky N.M. 1982. [Materials to the taxonomy of the genus Diaphanosoma (Cladocera, Sididae)] // Zoologitcheskiy journal. T.61. No.5. P.690-698 [in Russian].

Korovchinsky N.M. 1992. Sididae \& Holopediidae // Dumont H.J. (ed.). Guides to the identification of the microinvertebrates of the continental waters of the world. The Hague: SPB Acad. Publ. Vol.3. 82 p.

Korovchinsky N.M. 2004. [The Cladocera order Ctenopoda of the world (morphology, systematics, ecology, zoogeography)]. Moscow: KMK Scientific Press Ltd. 410 p. [in Russian].

Korovchinsky N.M. 2006. The Cladocera (Crustacea: Branchiopoda) as a relict group // Zool. J. Linn. Soc. Vol.147. P.109-124.

Kotov A.A., Sinev A.Yu., Korovchinsky N.M., Smirnov N.N., Bekker E.I., Sheveleva N.G. 2011. [Cladocera (Crustacea, Branchiopoda) from Zeya River basin (Amur region, Russia). 1. New taxa for fauna of Russia] // Zoologitcheskiy journal. T.90. No.2. P.131-142 [in Russian].

Paggi J.C. 1978. Revision de las especies Argentinas del genero Diaphanosoma Fischer (Crustacea, Cladocera) // Acta zoologica lilloana. Vol.33. No.1. P.43-65.

Sars G.O. 1901. Contributions to the knowledge of the fresh-water Entomostraca of South America. Part I. Cladocera // Arch. math. Naturw. Vol.23. No.3. P.1-102.

Responsible editor V.N. Ivanenko 